\title{
NALAR HISTORIS PERPOLITIKAN KAUM HAWA MASA NABI MUHAMMAD SAW
}

\author{
Wahyu Iryana \\ (UIN Sunan Gunung Djati Bandung) \\ wahyu_iryana@yahoo.com
}

\begin{abstract}
This paper tries to portray the role of women in the socio-political dimension in the era of the early arrival of Islam Islam is a tolerant religion that has given birth to a number of figures of brave women.. Just mention Khadijah Binti Khuwalid, Fatimah Az Zahra, Shafiyyah Binti Abdul Muthollib, Lubabah, Umul Fadhal Binti Harits, Asma Binti Amis (Wife Jafar), Fatimah Binti Khatab (Wife Said Bin Zaid), Sumayyah fighters women who sacrificed to make the nation proud and religion. For Islam, women are not only used as the secondline of life but rather, women can color the joints of life in a wider scope. So prominent is the role of women in the time of Prophet Muhammad SAW, that they were able to give up property for the glory of Islam they deserve to be called "de leidster van het verzet". Leaders of resistance like Summayah. The research method uses a descriptive approach by processing data into a writing with historical flow. The results of the study have been found that since Islam came Women have contributed to everything, starting from the economy as entrepreneurs, politicians, war fighters, housewives, and propagators of religious preaching.
\end{abstract}

\section{Keywords: Life, Women, Islam.}

Abstrak: Tulisan ini mencoba memotret peran perempuan dalam dimensi sosial politik di era awal kedatangan Islam. Islam adalah agama toleran yang telah melahirkan sejumlah tokoh perempuan pemberani. Sebut saja Khadijah Binti Khuwalid, Fatimah Az Zahra , Shafiyyah Binti Abdul Muthollib, Lubabah, Umul Fadhal Binti Harits, Asma Binti Amis (Istri Jafar), Fatimah Binti Khatab (Istri Said Bin Zaid), Sumayyah pejuang wanita yang rela berkorban untuk mengharumkan nama Bangsa dan Agama. Bagi Islam Perempuan sesungguhnya bukan hanya dijadikan secondline kehidupan saja melainkan dari itu, Perempuan bisa mewarnai sendi-sendi kehidupan dalam cakupan yang lebih luas. Begitu menonjolnya peranan perempuan di masa Nabi Muhammad SAW., hingga mampu merelakan harta benda untuk kejayaan Islam mereka layak dsebut"de leidster van het verzet". Pemimpin perlawanan seperti halnya Summayah. Metode penelitian menggunkan pendekatan deskriptif dengan mengolah data menjadi sebuah tulisan dengan alur historis. Hasil dari penelitian diperoleh bahwa sejak Islam datang Perempuan sudah memberikan kontribusinya di segala hal, dari mulai ekonomi sebagai pengusaha, politikus, pejuang perang, ibu rumah tangga, dan penyebar dakwah agama.

Kata Kunci: Kehidupan, Perempuan, Islam.

\section{A. PENDAHULUAN}

Islam menghargai perempuan
sebagai manusia yang terhormat.
Sebagaimana kaum Adam, perempuan
juga memiliki hak-hak kemanusiaan baik
dalam urusan sosial maupun politik.
Perempuan seperti halnya kaum laki-laki
adalah makhluk sosial yang tidak bisa
hidup sendiri. Ruang lingkup sosial itu
sendiri amat luas, dari kehidupan
keluarga sampai masyarakat dapat
dikatakan masalah sosial. Jadi peran
perempuan dalam keluarga dapat

dikatakan peran sosial karena keluarga merupakan salah satu bagian dari kehidupan bermasyarakat.

Penolakan para feminis pada sistem patriarki telah mewarnai gerakannya yaitu ingin meruntuhkan struktur patriarki yang dapat digolongkan menjadi dua pola umum. Pertama, melakukan transformasi sosial dengan perubahan eksternal yang revolusioner. Para feminis dalam kelompok ini berpendapat bahwa perempuan perlu masuk ke dalam dunia laki-laki agar kedudukan dan statusnya 
setara dengan laki-laki. Untuk itu perempuan perlu mengadopsi kualitas maskulin agar mampu bersaing dengan laki-laki.

Kedua, melakukan transformasi sosial melalui perubahan yang evolusioner. Berbeda dengan pola pertama, para feminis dalam kelompok ini percaya pada pemahaman deterministik biologi, yaitu menegaskan perbedaan alami antara lakilaki dan perempuan sehingga timbul apa yang di sebut kualitas feminin dan maskulin. Karenanya, kelompok ini berpendapat bahwa untuk meruntuhkan sistem patriarki dapat dilakukan dengan menonjolkan kualitas feminin.

Perbedaan pendekatan di antara kedua kelompok ini tentu telah menimbulkan perdebatan-perdebatan di antara kalangan feminis sendiri. Hal inilah yang memunculkan kritikan-kritikan yang dikemukakan oleh kedua kelompok tersebut. Para feminis yang tergabung dalam kelompok pertama atau para feminis modern mengkritik kelompok kedua sebagai pola yang justru melanggengkan sistem patriarki. Romantisme kualitas feminin akan menyebabkan perempuan tetap pada posisnya, yaitu sebagai figur pengasuh, pasif, dan pemelihara yang cocok untuk menjadi ibu dan pekerjaan-pekerjaan di sektor domestik.

Kelompok kedua (feminis kultural) mengkritik kelompok pertama karena pendekatannya tidak akan meruntuhkan sistem patriarkis pada dunia maskulin, tetapi hanya mengubah komposisi para aktor-aktornya saja di mana para perempuan sudah lebih banyak aktif di dunia maskulin yang tadinya didominasi oleh laki-laki. Para perempuan dianggap sudah menjadi male clone (tiruan laki-laki) di dunia maskulin, yaitu para perempuan yang telah mengadopsi kualitas maskulin (kompetitif, dominan, ambisi vertikal, dan memenuhi kepentingan pribadi). ${ }^{1}$

Perdebatan pun terjadi di kalangan para ulama, ketika Megawati Soekarno Putri akan menjadi Presiden Indonesia. Dengan berdasarkan hadits dan nash, hampir sebagian besar ulama Indonesia mengharamkan perempuan menjadi presiden, namun demikian akhirnya Mega pun menjadi orang nomor satu di Indonesia. Dampaknya pada kontestasi pemilihan politik tahun tahun berikutnya perempuan tampil dengan percaya diri, dan perundang-undangan mengharuskan $30 \%$ keterwakilan dalam pilihan politik harus memunculkan perempuan. Inilah fenomena yang terjadi saat ini, dengan demikian betapa perlunya kita untuk menengok kembali sejarah masa lalu umat Islam, khususnya sejarah perempuan pada masa Nabi Muhammad SAW.

Jazirah Arab pada waktu itu diapit oleh dua negara besar yaitu Persia di Timur dan Romawi di barat. ${ }^{2}$ Karena letak geografisnya yang amat strategis, Makkah menjadi tempat persinggahan para kafilah dagang yang datang dan pergi menuju ke kota pusat perniagaan. Di Makkah telah tersedia pasar-pasar sebagai tempat pertukaran barang-barang antar para saudagar dari Asia Tengah, Syam, Yaman, Mesir, India, Irak, Ethiopia, Persia, dan Rum. ${ }^{3}$

Secara umum masyarakat Arab pada saat itu merupakan masyarakat yang gemar berperang. Masalah kecil yang terjadi antara seseorang dengan yang lain dapat mengantarkan perang besar yang melibatkan beberapa suku. Kebanyakan akhlaq mereka sangat rendah, bahkan sama sekali tidak menghargai harkat dan martabat kaum perempuan. ${ }^{4}$ Kaum perempuan ditindas, dilecehkan, dan dibenci oleh kedua orang tua mereka. ${ }^{5}$ Perempuan pada saat itu sering di jadikan sebagai jaminan atau alat pembayaran hutang para suami atau para orang tua mereka. Bahkan lebih dari itu menurut sejarah bayi perempuan di kubur dalam keadaan masih hidup atau dibunuh. Sungguh keadaan yang sangat mengkhawatirkan para ibu yang akan melahirkan bayi-bayi mereka. Apalah daya mereka, karena mereka hidup di tengah-tengah masyarakat yang bercorak patriarkal yang emosional. 
Seperti itulah nasib dari sebagian besar perempuan pada zaman jahiliah yang bertuhankan berhala (paganisme). Mereka sama sekali tidak memiliki hak untuk hidup sebagaimana layaknya seorang manusia yang memiliki kebebasan untuk melindungi diri sendiri. Berhala yang mereka anggap tuhan pun tidak dapat menyelamatkan kaum perempuan dari penderitaan yang sedemikian rupa. Dalam kondisi masyarakat yang demikian itulah nabi Muhammad SAW diutus untuk pertama kali menyampaikan risalah yang hampir seratus persen berlainan dengan kebiasaan yang berlaku.

Maka dari itu, penulis mencoba membahas tentang peran sosial politik perempuan Arab pada saat Islam sudah mereka peluk dan menjadi pedoman hidup mereka. Dalam lembaran sejarah Islam, dijumpai keterangan bahwa perempuan mukminah memiliki banyak jasa yaitu selain ikut serta dalam berbagai peperangan dengan cara yang aktif dan positif, mereka juga memiliki kontribusi dalam upaya mengembangkan Islam.

\section{B. METODE PENELITIAN}

Pisau analisa untuk dapat memberikan penjelasan yang memadai, terutama dalam mengungkap fakta-fakta tentang apa, siapa, kapan, di mana, mengapa, dan bagaimana kehidupan sosial-politik perempuan sejak awal kenabian, dalam penelitian ini penulis berusaha semaksimal mungkin menerapkan dasar-dasar metode penelitian analitis deskripstif yaitu mengurai fakta-fakta berdasarkan datadata yang diperoleh. Penelitian yang dilakukan cenderung menggunakan rujukan Hadist-hadits dan Al-Qur'an serta Sirah Nabawi berdasarkan Historiografi Islam.

\section{HASIL DAN PEMBAHASAN}

Pada masa Rasulullah, banyak sekali contoh peranan sosial perempuan baik di dalam keluarga maupun di dalam masyarakat. Salah satu contohnya adalah Siti Khadijah. Khadijah binti Khuwalid adalah istri pertama Rasulullah yang sangat dicintainya, walaupun telah tiada. Khadijah r.a. memiliki sifat-sifat yang mulia, salah satunya yaitu sifat dermawan. Ia akan merasa bahagia ketika ia dapat memberikan sesuatu kepada orang lain. ${ }^{6} \mathrm{Hal}$ ini telah ia buktikan di dalam kehidupan rumah tangganya bersama Rasulullah SAW. Khadijah binti Khuailid, tergolong dalam keluarga Quraisy Abdul al-Uzza dan menduduki tempat terhormat sebagai istri pertama. Ia adalah seorang janda yang kaya raya dan dianugerahi sifat-aifat mulia karena kehidupannya yang berbudi luhur, sehingga terkenal dengan nama Thahira (suci). Menurut thabaqot Ibnu Sa'ad, sebagaimana yang dikutip oleh Jamil Ahmad dalam buku Seratus Muslim Terkemuka, mengatakan bahwa beliau adalah wanita terkaya kala itu. Rasulullah tidak menikah dengan perempuan lain selama Khadijah masih hidup. Siti Khadijah telah memberikan enam orang anak, dua orang putra; Qasim dan Abdullah, keduanya meninggal waktu masih bayi, dan empat orang anak perempuan; Fatimah, Zainab, Ruqoyah

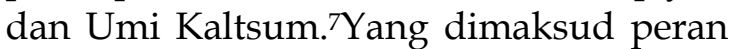
politik perempuan pada masa Rasulullah SAW di sini adalah suatu tindakan individu atau kelompok dalam mengatasi problematika kehidupan bermasyarakat dengan mengakui, menjalankan dan mempertahankan seperangkat undangundang (hukum) yang sah.

Pada masa Rasulullah, kaum perempuan Arab memulai aktivitasaktivitas politik mereka pada saat mereka mengakui Islam sebagai agama mereka atau mengakui bahwa tiada tuhan selain Allah dan Muhammad SAW adalah utusan Allah. Khadijah adalah orang yang pertama kali mengakui akan hal itu dan ia jugalah yang dapat memberi motivasi kepada Rasulullah, pada saat Rasulullah merasa khawatir dan gelisah akan dirinya dengan kondisi pada waktu itu. Setelah Khadijah, barulah kemudian diikuti oleh putri-putri beliau dan orangorang terdekat Rasulullah. Dari pihak kaum perempuan di antaranya adalah 
Shafiyyah binti Abdul Muthollib, Lubabah, Umul Fadhal binti Harits, Asma binti Amis (istri Jafar), Fatimah binti Khatab (istri Said bin Zaid), Summiyyah (ibu Ammar, jadi istri Yasir) dan sebagainya.

Orang-orang tersebut berasal dari golongan hamba sahaya dan orang desa. Mereka lebih kurang tiga tahun lamanya memeluk dan mengikuti seruan Nabi Muhammad SAW. Dengan diam-diam mereka pergi ke celah-celah bukit untuk beribadah kepada Allah. Hal ini dilakukan agar tidak diketahui kaum kafir Quraisy. Mereka sadar apabila hal ini diketahui oleh kaum kafir quraisy maka mereka akan mendapat rintangan dan bahaya dari mereka. ${ }^{8}$ Seperti yang dialami Sumayyah dan keluarganya. Mereka disiksa dengan teramat kejam, agar mau mengikuti kemauan Abu Jahal, namun tiada terdengar sepatah katapun dari keluarga Sumayyah selain rintihan semata, karena itu Abu Jahal meningkatkan penyiksaannya agar keduanya menyatakan kemurtadannya dari agama Islam secara terus terang.

Perjalanan hidup Sumayyah dicatat dalam lembaran sejarah dengan tinta emas, hingga kini namanya tetap abadi. Perempuan yang pertama kali mati sahid dalam Islam ini, kematiannya dapat dijadikan lentera penerang iman dan dapat dijadikan contoh teladan dalam menegakkan prinsip. Ia rela mengorbankan jiwa raganya demi mempertahankan keimanan. Ia merupakan orang-orang angkatan pertama dalam Islam.95elain Sumayyah, Hamamah (ibu Bilal bin Rabah) juga mengalami penyiksaan sampai ia meninggal dunia. Lain halnya dengan Umu Unais dan anak perempuannya yang bernama Latifah, mereka disiksa oleh tuannya, namun kemudian ia dibebaskan oleh Abu Bakar ra. Abu Bakar juga telah memerdekakan Nahdiah dan anak perempuannya yang sedang disiksa oleh tuannya. ${ }^{10}$ Penyiksaan pun dilakukan oleh Umar bin Khatab kepada adiknya yang bernama Fatimah, ketika ia mengetahui adiknya masuk Islam. ${ }^{11}$

Kekejaman-kekejaman yang dilakukan oleh kaum kafir Quraisy terhadap umat Islam pada saat itu mendorong Nabi untuk mengungsikan para sahabatnya ke luar Makkah. Pada tahun ke lima kerasulan Nabi menetapkan Habsyah (Ethiopia) sebagai negeri tempat pengungsian. Negus, raja Habsyah tersebut adalah seorang raja yang adil. ${ }^{12}$

Kaum muslimin yang berangkat hijrah ke negeri Habsyah berjumlah 15 orang, terdiri dari sepuluh orang laki-laki dan lima orang perempuan. Kelima orang muslimah tersebut adalah, Ruqoyyah binti Muhammad SAW, Sahlah binti Suhail, Umu Salamah binti Abu Umayah, Laila binti Kaltsamah, dan Umu Kaltsum. ${ }^{13}$

Itulah hijrah pertama yang dilakukan oleh para muslimah Arab ke negeri Habsyah (Abaysinia) pada tahun 615 M, karena untuk mempertahankan agamanya mereka bersedia melepaskan keluarga dan klan mereka. ${ }^{14}$ Setelah tiga bulan dalam pengungsian mereka kembali ke Makkah karena mereka mendapatkan kabar tentang perubahan kondisi Makkah pada saat itu. ${ }^{15}$ Hijrah mereka ke Habsyah tidak hanya sekali tetapi dua kali. Pada hijrah yang kedua kali inilah jumlah umat Islam semakin banyak, yaitu sekitar 101 orang laki-laki dan perempuan. ${ }^{16} \mathrm{Hijrah}$ kedua tersebut dilakukan karena kaum kafir Quraisy melakukan pemboikotan terhadap kaum muslimin yang terjadi pada tahun $617 \mathrm{M}$. Di antara mereka ada yang meninggalkan suami dan keluarga. Para muslimah tersebut tidak hanya ikut hijrah ke Habsyah tapi mereka juga hijrah ke Madinah.

Sebelum hijrah ke Madinah, Rasulullah mengadakan tiga kali pertemuan dengan kaum Ansor (dari Madinah), yang dilakukan secara sembunyi-sembunyi. Pada pertemuan kedua mereka berba'iat kepada Rasulullah, dan ini disebut Bai'at Aqobah pertama yaitu pada tahun $622 \mathrm{M}$. Pada pertemuan ketiga yakni pada musim haji 
berikutnya yaitu pada tahun $623 \mathrm{M}$, dengan jumlah lebih banyak lagi yaitu 73 orang laki-laki dan dua orang perempuan, terjadi Bai'at Aqobah kedua atau yang lazim disebut Baiatunisa. Perempuan pertama yang melaksanakan hijrah ke Madinah adalah Umu Salamah, Laila binti Abi hatsmah, Syaifa binti Abdullah juga Fathimah binti Qois bin Khalid, Fatimah binti Khatab, dan lain-lain. ${ }^{17}$

Bai'at ini menjadi tonggak berdirinya sistem Islam dalam wujud sebuah negara berdaulat, dan para perempuan Ansor menyadari itu sebagai amanah yang harus mereka tunaikan.18 Selain itu menurut Haifa A Jawad, bai' at dalam Islam adalah sebuah lembaga politik yang penting di gunakan oleh rakyat atau umat untuk memberikan atau menjamin adanya legitimasi atas sistem politik. Bai'at mencakup janji oleh rakyat untuk loyal kepada sistem dan pimpinannya sepanjang pemimpin tersebut memegangi prinsip-prinsip Islam.

Oleh karenanya, bai'at adalah sebuah perjanjian yang diisi tiga unsur. Pertama, pemimpin (pihak yang harus diberi janji atau pengakuan), kedua, rakyat atau umat (pihak yang harus memberikan kesetiaan dan loyalitasnya). Dan yang ketiga yaitu Syari'ah (unsur yang harus di hargai dan dipegangi oleh pemimpin dan rakyat). ${ }^{19}$ Rasulullah SAW mengambil janji dari kaum perempuan sebagaimana dari laki-laki, adalah untuk mendukung adanya sebuah kebenaran dan mentaatinya.

Setelah terjadinya bai'at tersebut, maka perempuan muslimah berangkat ke Madinah. Peran serta perempuan dalam hijrah baik ke Habsyah maupun ke Madinah jelas merupakan tindakan politik, sebagai tanda ketaatan mereka pada pimpinannya, yaitu Rasulullah SAW. Disamping itu secara politis, hijrah ke Habsyah adalah upaya untuk menyelamatkan perjuangan, agar jumlah umat Islam yang masih sedikit kala itu tidak dibrangus oleh kekuatan musyrikin Quraisy.
Para perempuan yang ikut serta dalam hijrah ke Habsyah pun menghadapi kesulitan yang tidak sederhana. Fatimah binti al Mujadil, Rahmah binti Auf bin Dhobairah, Fukaihah binti Yasir, dan Umu Habibah binti Abu Sufyan ditinggal para suami mereka yang masih murtad. Sementara itu, Raithah binti al Harits bersama-sama anaknya Musa, Aisyah dan Zainab meninggal dalam perjalanan kembali ke Makkah karena mereka kehabisan air minum. Hijrah ke Madinah pun merupakan manuver politik yang penting. Telah diketahui bahwa syari'at Islam di Makkah tidak mendapat tempat yang memadai, karena sistem kemusyrikan begitu menguasai. Atas petunjuk dan pertolongan Allah, tampilah Madinah (dahulu Yastrib) sebagai wilayah tempat risalah Islam dapat tegak dengan seluruh sendinya dan dalam berbagai dimensinya. Di Madinah inilah Rasulullah mulai membangun peradaban Islam yang bermakna, sebagai penyelamatan peradaban manusia yang membangun terhormat.

Para perempuan Arab pada saat itu dengan kesadaran politiknya turut hijrah ke Madinah walaupun menghadapi kesulitan yang bermacam-macam. Ruqoyyah binti Rasulullah dan Zainab mengalami keguguran kandungan dalam perjalanan hijrah. Umu Aiman tetap berhijrah walaupun dengan berjalan kaki dan tanpa bekal apapun kecuali pemberian orang di jalan. Itulah perjuangan mereka untuk menegakkan daulah Islamiyah. ${ }^{20}$ Perjuangan kaum perempuan pada masa Rasulullah tidak hanya sampai pada hijrah saja, namun mereka turut serta juga dalam peperangan, meskipun secara fisik lebih lemah dari laki-laki. Mereka ikut serta dalam konflik bersenjata, baik dengan cara mempersiapkan makanan dan minuman serta merawat orang yang terluka ataupun memainkan peran penting dalam pertarungan yang sebenarnya ketika dibutuhkan. 
Di antara teladan-teladan perempuan yang mengambil peran aktif dalam beberapa pertempuran antara lain adalah Shafiyyah, bibi nabi SAW yang telah memperhatikan benteng di Madinah pada waktu perang Khandak. Ia memperhatikan seorang penyusup yang telah menemukan pertahanan benteng, lalu mengatur strategi untuk mendesak dan membunuh penyusup tersebut sebelum mereka bisa melakukan hal-hal yang berbahaya bagi kaum perempuan dan anak-anak. ${ }^{21}$ Dalam berbagai pertempuran yang pernah terjadi, para perempuan turut aktif dalam menegakkan daulah Islamiyah, pada perang Badar, mereka melakukan tugas untuk memberi minum para perajurit dan merawat yang luka. Dalam perang Uhud, Nusaibah binti Ka'ab ia melindungi Rasulullah SAW dari serangan musuh dengan pedangnya, bahkan sesekali beliau sempat melepaskan anak panah. (lampiran no.9). Pada peristiwa Hudaibiyah, kecerdasan Umu Salamah dalam melakukan komunikasi politik terbukti. Ketika para sahabat merasa keberatan dengan isi perjanjian Hudaibiyah antara kaum muslimin dan musyrikin Quraisy, yang dirasakan menguntungkan kaum Quraisy mereka lalu tidak mau mentaati perintah Rasulullah agar menyembelih binatang kurban dan mencukur rambut. Ketika itulah Umu Salamah menyampaikan usulnya agar Rasulullah menyembelih kurban beliau dan mencukur rambut beliau tanpa harus berbicara apa-apalagi pada para sahabat, karena tindakan beliau itu merupakan penegasan komitmen Rasulullah pada perjanjian Hudaibiyah, seperti yang diperintahkan oleh Allah. Walaupun sepintas perjanjian itu tampak merugikan umat Islam, ternyata usulan Umu Salamah itu benar adanya. Para sahabat seketika sadar akan kesalahan mereka, lalu melaksanakan apa yang diperintah oleh Allah dan Rasulnya ${ }^{22}$. Berikut kita analisis bagaimana kaum perempuan memiliki peran penting dalam bidang sosial dan politik pada masa penyebaran Islam awal:

\section{Bidang Sosial}

Perjalanan hidup manusia memang selalu mengalami perubahan begitu juga dengan perjalanan sejarah umat Islam. Dalam kehidupan sosial masyarakat akan ditemukan perbedaanperbedaan yang tumbuh dan berkembang dalam masyarakat tersebut. Seperti perbedaan posisi perempuan Arab yang terjadi pada akhir zaman jahiliah atau pada masa awal kedatangan Islam, kaum perempuan menduduki posisi yang amat rendah bila dibandingkan dengan kaum laki-laki. Pepatah mengatakan bahwa harga diri seseorang sebesar kebaikan yang diperbuatnya, namun demikian pada waktu itu mereka sama sekali tidak mengenal arti sebuah nilai kebaikan. Masyarakat Arab hanya mengenal kekuatan otot, siapa yang kuat dialah yang menang, sehingga sebuah harga diri mereka didasarkan pada otot yang kuat. Baru setelah Islam dapat tumbuh dan berkembang di dalam masyarakat Arab, pada saat itu pula posisi kaum perempuan mengalami perubahan. Kaum perempuan Arab dihargai dan dihormati, juga dilindungi di bawah naungan ajaran Islam. Kaum perempuan hidup di dalam sebuah ikatan kekeluargaan (pernikahan) yang suci. Mereka dikasihi dan disayangi oleh suami mereka, bahkan lebih dari itu seorang ibu lebih berhak atas kepatuhan anaknya kepada orang tuanya. Kaum perempuan Arab tidak lagi menjadi sebuah barang yang dapat diperjualbelikan atau dapat diwariskan. Kemuliaan Agama Islam berjalan mengiringi dan melindungi harga diri kaum perempuan. Maka dari itu perempuan memiliki kontribusi yang besar dalam hubungan keluarga dan hubungan masyarakat.

\section{Bidang Politik}

Implementasi dasar keikutsertaan perempuan muslim berpolitik adalah refleksi kehidupan muslimah pada masa Rasulullah. Perempuan tidak hanya memiliki kontribusi sosial tetapi juga 
politik. Sebagai warga masyarakat, perempuan memiliki tanggung jawab yang sama dengan kaum laki-laki untuk mempertahankan sebuah kekuasaan Islam. Hal inilah yang telah dilakukan oleh para perempuan Arab. Mereka rela mengorbankan jiwa raga dan harta bendanya untuk Islam, meskipun hal ini dilakukannya dalam kondisi tertentu. Mereka merupakan bagian positif yang mampu ikut serta dalam memikul beban dan tanggung jawab dalam masyarakat. Sebagai anggota masyarakat yang memiliki kemampuan dan kesadaran yang tinggi mereka mampu mengaktualisasikan dirinya dalam wilayah politik bersama-sama kaum pria untuk berjihad.

Dalam bidang politik jihad diartikan sebagai perjuangan memerangi orang-orang kafir untuk meninggikan kalimat Allah SWT. Peran pundamental jihad ialah menegakan agama dan menjaganya, menyingkirkan kemusyrikan menghadang segala bentuk intervensi yang mengancam syariat atau daulah Islam serta tatanannya. Menjaga agama yang sekaligus merupakan tujuan utama dari jihad.

Jihad hukumnya fardu kifayah menurut jumhur Fuqoha. Pengertiannya, jika sebagian orang sudah melaksanakannya, berarti kewajiban ini gugur bagi yang lain, tetapi jika tak seorang pun yang melaksanakannya berarti semua orang berdosa. Ada kalanya jihad menjadi fardu $a^{\prime}$ in dalam kondisikondisi tertentu yang dikecualikan, seperti jika invasi musuh ke wilayah kaum muslim, atau ketika pemimpin menyerukan kepada seseorang untuk berperang. Sebuah maksud dari jihad adalah memuliakan agama dan menjaga keselamatan wilayah kaum muslimimin. ${ }^{23}$

Tidak mengherankan apabila banyak kaum perempuan Arab yang berantusias untuk ikut berjihad di medan perang untuk menjadi seorang pejuang. Tentang hal ini banyak riwayat yang mengungkapkannya di antaranya yaitu, dalam berbagai pertempuran yang pernah terjadi para perempuan Arab turut ambil bagian. Salah satu contohnya adalah pada peristiwa Perang Badar, mereka di tugaskan untuk memberi minum para perajurit dan merawat yang luka-luka. Dalam perang uhud Nusaibah binti Ka'ab melindungi rasulullah SAW dari serangan musuh dengan pedangnya bahkan sesekali beliau dapat melepaskan anak panah. ${ }^{24}$

Dalam peristiwa perang uhud tersebut banyak perempuan Arab yang ikut berperang. Diantaranya adalah Aisyah (istri Rasulullah), Ummu Sulaim, Ummu Sulaith al Ansoriyah, Hamnah binti Jahsy, dan lain-lain. Mereka tidak hanya menyediakan minuman atau makanan tetapi mereka juga membawa dan merawat para mujahid yang terluka ke Madinah. Sekali-kali mereka juga berhadapan langsung dengan musuh. ${ }^{25}$

Pada peristiwa perang uhud tersebut ada segolongan perempuan berada di belakang yang terbuat dari batu pada pagi hari. Tempat ini sekaligus merupakan tempat persinggahan orangorang yang terpandang maupun orangorang yang lemah, seperti Abu Hudzaifah al Yaman, Tsabit bin Waqash. Ketika Rasulullah SAW pergi untuk berperang beliau menempatkan istri-istri beliau di benteng Hasan, karena ini merupakan benteng terkuat. ${ }^{26}$

Peristiwa lainnya yaitu perempuan juga turut aktif dalam pengepungan Khaibar. Jumlah perempuan yang terlibat dalam perang khaibar mencapai 15 orang. Mereka terlibat secara aktif bersama kaum lakilaki dalam perang ini. Menurut Imam Ahmad Rasulullah SAW memberikan ghanimah kepada perempuan yang ikut berperang tersebut. ${ }^{27}$

Sebagaimana yang telah dikemukakan dalam bab tiga, bahwa peran politik perempuan Arab diawali dengan masuknya mereka ke dalam Islam lau berbaiat, berhijrah berperang. Perempuan Arab tidak hanya berperan sampai di situ, mereka turut serta juga dalam mengatasi masalah politik yang 
terjadi pada masa tersebut. Ummu Salamah adalah Perempuan yang cerdas yang dapat mengatasi masalah politik yang dihadapi oleh Rasulullah SAW.

Demikianlah peran politik para perempuan muslimah dalam melakukan aktivitas politiknya. Hal ini menunjukan bahwa perempuan muslimah memiliki kesadaran yang tinggi dalam berpolitik. Keterlibatan perempuan dalam usaha untuk mewujudkan sebuah wilayah kekuasaan Islam merupakan kontribusi yang patut dibanggakan. Kontribusi tersebut telah membuktikan bahwa mereka sebagai perempuan mampu melaksanakan tanggung jawabnya secara maksimal.

Atas nama hak asasi manusia, di bawah kepemimpinan Rasulullah SAW, kaum perempuan dapat menikmati kebebasan penuh untuk mengembangkan jati diri dan kepribadiannya. Mereka ikut serta ambil bagian dalam membentuk masyarakat. Lebih dari itu kaum perempuan dapat memanfaatkan kemerdekaan dan kebebasan yang dimilikinya, selama itu tidak melanggar ajaran agama. ${ }^{28}$

Telah diketahui bahwa aktivitas kaum perempuan Arab pada masa Rasulullah SAW di dalam rumah tangga, tidak hanya sekedar mengandung, melahirkan dan menyusui tetapi juga mendidik putra-putrinya. Para perempuan Arab membutuhkan ilmu pengetahuan disamping untuk dirinya sendiri juga sebagai bekal untuk mendidik putra-putrinya. Mereka berharap kelak dikemudian hari mereka memiliki generasi penerus yang cerdas dan dinamis. Berkaitan dengan hal tersebut, maka pada masa Rasulullah SAW banyak kaum perempuan Arab yang berantusias dalam menuntut ilmu, terutama pada saat Islam mulai tumbuh dan berkembang di Madinah.

Mengenai hal tersebut telah di kabarkan dalam sebuah hadits bahwa, kondisi perempuan Makkah (Muhajir) berbeda dengan kaum perempuan Madinah (Ansor). Hal ini dapat dibuktikan dengan pengakuan Aisyah, istri rasulullah SAW bahwa, ia mengagumi perempuan Ansor. Ketika Aisyah menyampaikan hal ini dihadapan kaum perempuan Muhajirin, bahwa perempuan Ansor suka menuntut ilmu. ${ }^{29}$ Perempuan Arab merupakan pendidik utama dan pertama bagi anaknya, Khususnya pada masa-masa balita. Potongan syair Arab menyatakan "Al Umm madrasah..."(ibu adalah tempat belajar). ${ }^{30}$

Menurut Quraish Shihab dalam bukunya berjudul, Lentera Hati, mengatakan bahwa, "ibu" dalam bahasa al-Qur'an dinamai dengan Umm, dari akar kata yang sama dibentuk kata Imam (pemimpin) dan umat. Kesemuanya bermuara pada makna "yang dituju" atau "yang diteladani", dalam arti pandangan harus "tertuju pada umat, pemimpin dan ibu untuk diteladani. Umm atau "ibu" melalui perhatiannya kepada anak serta keteladannya, serta perhatian anak kepadanya, dapat menciptakan Pemimpin-pemimpin dan bahkan dapat membina umat. Sebaliknya jika yang melahirkan seorang anak tidak berfungsi sebagai umm, maka umat akan hancur dan pemimpin (imam) yang wajar untuk diteladani pun tidak akan lahir. ${ }^{31}$

Telah dikemukakan dalam sebuah hadits bahwa, ibu adalah yang pertama berhak menerima kepatuhan seorang anak kepada orang tuanya. Hal ini bukan hanya disebabkan karena ibu memikul beban yang berat dalam mengandung, melahirkan dan menyusukan tetapi juga karena ibu telah berperan untuk membimbing umat atau masyarakat.

Fungsi dan peranan inilah yang menjadikannya sebagai "umm" atau "Ibu". Demi suksesnya fungsi tersebut Allah menganugrahkan kepada kaum permpuan struktur biologis dan cirri psikologis yang berbeda dengan kaum pria. Peranan ibu sebagai pendidik generasi bukanlah suatu hal yang mudah. Peranan itu tidak dapat di sepelekan atau dikesampingkan. ${ }^{32}$ 
Telah tertoreh di dalam sejarah Islam bahwa para perempuan Arab telah banyak menunjukan keteladanan mereka di dalam mendidik anaknya. Salah satu yang menjadi contohnya yaitu Asma binti Abu Bakar yang menjadi istri Zubair, dialah yang banyak memberikan peran dalam membentuk kepribadian putranya Abdullah bin Zubair. Ia menjadi seorang yang shaleh, bertaqwa, pemberani dan ketika besar ia menjadi pemimpin umatnya. ${ }^{33}$ demikian juga dengan Fatimah binti Rasulullah SAW, Ia telah mendidik Hasan dan Husain.

Demikianlah Islam dengan ajarannya telah membimbing kaum perempuan untuk membina putraputrinya dalam bermasyarakat. Secara tidak langsung hal ini merupakan sebuah kontribusi kaum perempuan dalam membentuk suatu masyarakat yang Islami.

Rasulullah SAW bersabda, Perempuan adalalah tiang negara apabila perempuannya baik maka berjayalah negara, bila ia rusak maka hancurlah negara.

Hadits tersebut secara tidak langsung telah menyatakan bahwa perempuan turut menentukan keberhasilan sebuah negara. Dari sini jelaslah bahwa hukum dasar berpolitik bagi kaum perempuan bukan hanya dibolehkan melainkan dianjurkan untuk ukut andil dalam berpolitik secara santun sesuai tuntunan ajaran Islam yang dicontohkan Nabi Muhammad SAW.

\section{PENUTUP}

Setelah menguraikan dan membahas tentang perjalanan Kehidupan sosial politik kaum perempuan pada masa Nabi Muhammad SAW (610M-632M), dapat ditarik beberapa kesimpulan sebagai berikut.

Kondisi perempuan pada masa awal Islam sangat memprihatinkan. Hal ini dikarenakan masyarakat Arab pada saat itu belum mengenal adanya normanorma hukum yang dapat membawa mereka ke jalan yang lurus. Selain itu kondisi geografis yang kurang bersahabat, menuntut mereka untuk mempertahankan kehidupan dengan cara yang tidak baik (merampok, berperang dan sebagainya). Hal ini umumnya terjadi pada masyarakat desa (Badui), sehingga kekuatan fisik amat diutamakan. Kaum laki-laki yang memiliki fisik yang lebih kuat dari fisik kaum perempuan sangat diagungkan, sehingga kaum perempuan amat dihinakan. Sudah menjadi suatu kebiasaan bahwa bangsa Arab merasa bangga apabila memiliki banyak anak laki-laki, dan merasa hina apabila memiliki anak perempuan, sehingga terjadilah pembunuhan terhadap bayibayi perempuan.

Setelah bangsa Arab memeluk agama Islam, kondisi yang demikian menghinakan telah berubah menjadi kondisi yang patut di banggakan. Kaum perempuan dihormati dan dibanggakan, antara laki-laki dan perempuan saling melindungi dan menghormati baik di dalam keluarga maupun di dalam masyarakat. Hal ini terjadi karena mereka telah memiliki peraturan-peraturan (Hukum) kehidupan dalam agama yang sempurna dan atas bimbingan seorang Rasul yang mulia. Kaum perempuan pada waktu itu dapat melakukan aktivitasaktivitas yang positif, yang dapat membangun kepribadian mereka sebagai makhluk yang sempurna.

Perempuan Arab yang hidup di bawah naungan agama Islam dapat berperan aktif dan positif dalam wilayah domestik dan publik. Mereka dapat melakukan aktivitas-aktivitas sosial dan politik secara maksimal dengan dasar, tujuan dan motivasi yang baik. Melalui peranan itulah mereka dapat mengaktualisasikan potensi yang dimilikinya sehingga mereka mendapatkan kedudukan yang layak dalam masyarakat.

\section{E. UCAPAN TERIMA KASIH}

Penulis Ucapakan terima kasih kepada semua pihak yang turut membatu 
penulisan ini, Kementrian Agama Rebublik Indonesia, Pemerintahan Provinsi Jawa Barat, Para santri Pondok Pesantren Universal Bandung, termasuk penyediaan data dari saudara Wahyu Iryana. Semoga penelitian ini besa memeberi informasi tambahan untuk kepentingan peneliti yang se-tema dan ghiroh akedemis penelitian selanjutnya.

\section{Referensi}

1 Mansur Fakih dkk, Membincang Feminisme ; Diskursus Gender Perspektif Islam (Surabaya : Risalah Gusti, 2000 ), hlm. 209 - 211.

2 Ibid. hlm. 12 .

3 Abdurrahman Asy Syarqowi, Muhammad Sang Pembebas, terj. Ilyas Siraj ( Yogyakarta : Pustaka Pelajar, 1998 ), hlm. 8.

${ }^{4}$ Muhibbin, Hadits - Hadits Politik, hlm. 17.

5 Fatima Umar Nasif, Menggugat Sejarah Perempuan, terj. Burhan Wira Subrata dan Kundan D. Nuryaqien ( Jakarta : CV Cendekia Sentra Muslim, 1999 ), hlm. 51.

6 Tarbawi, perempuan Ilham dari Surga, Edisi 56 th 4/3 April 2003 M, hlm. 10.

7 Jamil Ahmad, Seratus Muslim Terkemuka, (Jakarta: Pustaka Firdaus, 1996), hlm. 78-79.

8 Moenawar Chalil, Kelengkapan Tarikh, hlm.177.

${ }^{9}$ Aba Firdaus al Halwani, Wanita-Wanita, hlm. 210-212.

${ }^{10}$ Moenawar Chalil, Kelengkapan Tarikh, hlm. 220-231.

11 Ibid. hlm. 269.

12 Badri Yatim, Sejarah Peradaban Islam, (Jakarta: PT Raja Grafindo Persada, 2002), hlm. 22.

13 Moenawar Chalil, Kelengkapan Tarikh, hlm. 269.

14 Ira M Lapidus, Sejarah Sosial Umat Islam, (Jakarta:,PT Raja Grafindo persada, 1999), hlm.36.

${ }^{15}$ Moenawar Chalil ,Kelengkapan, hlm. 268.

16 Ibid. hlm. 342.

17 Ibid. hlm 407.

18 Amatullah Shafiyyah dkk, Kiprah Politik, hlm. 32-33.

19 Haifa A. Jawad, Otentisitas Hak-Hak Perempuan (Perspektif Islam atas Kesetaraan Gender ) terj. Ani Hidayatun dkk. (Yogyakarta: Pajar Pustaka Baru, 2002), hlm. 260-270.
20 Amatullah Shafiyyah dkk, Kiprah Politik, hlm. 31 .

21 Haifa A Jawad, Otentisitas Hak-hak, hlm. 275.

22 Amatullah, Haryati S, Kiprah Politik, hlm. 34.

23 Asma M. Ziyadah, Peran Politik Wanita dalam Sejarah Islam. terj. Khatur Suhardi (Jakarta : Pustaka al Kautsar, 2001), hlm. 126.

24 Amatullah Syafiyyah dkk, Kiprah Politik, hlm.34.

25 Ibid. hlm. 136-137.

26 Asma .M. Ziadah, peran Politik, hlm.136.

27 Cahyadi takariawan, Fikih Politik Kaum Perempuan, (Yogyakarta, Tiga lentera Utama, 2002), hlm.86.

${ }^{28}$ Haifa A. Jawad, Otentisitas Hak-Hak, hlm. 34.

29 Zaitunah Subhan, Tafsir Kebencian, hlm.59.

30 ibid. hlm. 76

31 Abu Fatiya al Adnani, Agenda an- Nisa, (Bumi Allah, Qisti Saufa Abadi 2001), hlm.46.

32 Ibid. hlm.259

33 Abu Fatiya al Adnani, Agenda an-Nisa, ( Bumi Allah, Qisti Saufa Abadi, 2001), hlm. 46.

Buku

Abu Syuqqoh, Abdul Halim. 1999. Kebebasan Wanita, jilid 11, Jakarta, Gema Insani Press

Ahmad, Jamil. 1996, Seratus Muslim Terkemuka, ,Jakarta, Pustaka Pirdaus

A, Jawad, Haifa, 2002, Otentisitas Hak-Hak Perempuan, (Perspektip Islam Atas Kesetaraan Gender), penj, Ani Hidayatun dkk, Yogyakarta, Fajar Pustaka Baru

Al-Qur'an dan Terjemahannya. 2002. Juz 1 - 30 edisi baru. Surabaya : UD. Mekar

Al- Husaini, al - Hamid H.M.H. 1997, Baitun Nubuwwah, Rumah Tangga Nabi Muhammad SAW, Bandung Pustaka Hidayah

Al Hawani Aba Firdaus. 1996. Wanita Wanita Pendamping Rasulullah Yogyakarta : Al Mahali Press.

Abdul Ghafur, Waryono dan Muhammad Isnanto2002. Gender Dan Islam. Yogyakarta : PSW IAIN Sunan Kalijaga. 
Abdurrahman, Dudung. 1999. Metode Penelitian Sejarah. Jakarta : Logos.

Al-Ghazali, Abdul Hamid. 2001. Meretas Jalan Kebangkitan Islam. Solo : Intermedia, cet. II.

Al-Adnani, Abu Fatiya. 2001. agenda anNisa, Bumi Allah : Qisti Saufa Abadi.

Asy Syarqowi, Abdurrahman. 1998. Muhammad Sang Pembebas, terj. Ilyas Siraj, Yogyakarta : Pustaka Pelajar.

Burke, Peter 2001. Sejarah dan Teori Sosial, Jakarta : Yayasan Obor.

Chalil, Moenawar 1984, Nilai Wanita, Solo, Ramad Hani

Fakih, Mansur dkk 2000. Membincang Feminisme ; Diskursus Gender Perspektif Islam. Surabaya : Risalah Gusti.

Hibbah Rauf Izzat. 1997. Wanita dan Politik dalam Pandangan Islam, terj. Burhanuddin Fanani. Bandung : Remaja Rosda Karya

Kartodirjdo, Sartono

1982. Pemikiran Perkembangan Historiografi Indonesia Suatu Alternatif . Jakarta : PT Gramedia

Lapidus, M, Ira. 1999, Sejarah Sosial Umat Islam, jilid, II, Jakarta, PT Raja Grafindo

Muhamad, Ziyadah Asma. 2001, Peran Politik Wanita Dalam sejarah Islam, terj, Katur Suhardi, Jakarta: Gramedia kerjasama dengan PPIM IAIN Jakarta.

Muhibbin. 1996. Hadits - Hadits Politik. Yogyakarta : Pustaka Pelajar.

Munhanif, Ali. 2002. Perempuan dalam Literatur Islam Klasik. Jakarta : Gramedia kerjasama dengan PPIM IAIN Jakarta.

Nasif, Fatima Umar. 1999. Menggugat Sejarah Perempuan, terj. Burhan Wira Subrata dan Kundan D. Nuryaqien. Jakarta : CV Cendekia Sentra Muslim.

Shafiyyah, Amatullah dan Haryati, Soeripno, 1999. Kiprah Politik Muslimah : Konsep dan
Implementasinya. Jakarta : Gema Insani Press

Soekanto, Soerjono. 1982. Sosiologi Suatu Pengantar. Jakarta : CV Rajawali.

Surbakti, Ramlan. 1992. Memahami Ilmu Politik. Jakarta : Grasindo.

Tarbawi. 2003, Wanita Ilham dari Surga, Jakarta, PT Media Amal Tarbawi, edisi56, th 4-3 April

Takariawan, Cahyadi. 2002. Fikih Politik Kaum Perempuan, Yogyakarta : Tiga Lentera Utama.

Quraish. M. Shihab. 1999, Lentera Hati, Bandung : Mizan 